\title{
Criminal Law Enforcement of Money Laundering as a Community Protection Effort Against Economic Crime in Indonesia
}

\author{
Sri WahyuningsihYulianti ${ }^{1}$, Jamal Wiwoho ${ }^{2}$, Muhammad Rustamaji ${ }^{3}$ \\ ${ }^{1.2 .3}$ Universitas Sebelas Maret \\ Surakarta, Indonesia \\ sw.yuli_klt@yahoo.com
}

\begin{abstract}
In the era of globalization, science and technology advances have resulted in the emergence of global economic crimes or transnational crimes. One of the criminal acts in the economic field is money laundering, which is clearly an illegal act that has the potential to cause negative effects that can threaten economic stability and the integrity of the state financial system, as well as endanger the joints of people's- lives. Legal problems or issues occur in the law enforcement process for money laundering because there has not been a harmonious relationship between law enforcement officers such as POLRI investigators, KPK, Prosecutors and other related parties, especially at the investigation stage. In addition, the investigation is still being questioned about who has more authority to carry it out considering money laundering is still always associated with the crime of origin, whether from cases of corruption, narcotics-psychotropic, human trafficking, fraud, banking, or insurance.
\end{abstract}

Keywords- Money Laundering, Law Enforcement, Economic Crime.

\section{INTRODUCTION}

The definitions and scopes of economic crime is commonly referred to economic crimes, crime as business, business crime, abuse of economic power or economic abuses. Economic development efforts that are being carried out by developing countries in the world are generally oriented towards efforts to improve and raise the level of living of the people in these countries so that they can live like people in other countries - in developed countries. One of the criminal acts in the economic field is money laundering, which is clearly an illegal act that has the potential to cause negative effects that can threaten economic stability and the integrity of the state financial system.[1]

This crime of money laundering has been regulated in Law Number 15 of 2002 concerning the Crime of Money Laundering as amended by Law Number 25 of 2003 concerning Amendments to Law Number 15 of 2002 related to Crime of Money Laundering. Because the above Act needs to be adapted to the development needs of law enforcement, practice, and international standards; therefore, it needs to be replaced with a new law, which is regulated in Law Number 8 of 2010 concerning the Prevention and Eradication of the Crime of Money Laundering, hereinafter abbreviated and called (UU TPPU).[2]

The term money laundering comes from the United States, this term has a long history since 1930, at that time the perpetrators of organized crime hid and disguised the proceeds of crime by investing in laundry companies. Therefore, arrangements were made for the Prevention and Eradication of the Crime of Money Laundering, considering the impact caused by money laundering activities in the economy and to effectively comply with the principles of supervision of Bank Indonesia, Center for Financial Transaction Reports and Analysis (PPATK) according to international standards. For the Government, another impact is the increase in financial crimes and it creates high social costs, especially for costs in improving law enforcement efforts.[3]

Things related to Money Laundering Law determine the provisions for investigation, prosecution and examination in court by expanding the duties and authorities of law enforcement officers as regulated in the Criminal Procedure Code. Article 68 and Article 69 of the Anti-Money Laundering Law states The Money Laundering Law provides certain authorities, rights and obligations for related institutions, such as law enforcement officers, supervisory and regulatory agencies, reporting parties including financial service providers and providers of other goods and/or services, and the Financial Transaction Reports and Analysis Center (hereinafter abbreviated as PPATK) as an institution tasked with preventing and eradicating the crime of money laundering in assessing the process of concealing the origins of the proceeds of crime (follow the money) until the act of implementing the Anti-Money Laundering Law for perpetrators of money laundering. [4]

PPATK in Article 1 point 2 of the Anti-Money Laundering Law is an independent institution established in the context of preventing and eradicating the crime of 
money laundering, which is placed as a focal point, which has the main function of providing financial intelligence information to law enforcement officials, regarding alleged criminal acts of money laundering or alleged predicate offence.[5]

Problems or legal issues that occur in the process of law enforcement for the crime of money laundering is that there has not been a harmonious relationship between law enforcement officers, especially at the investigation stage; it is still being questioned about who has more authority to carry it out considering that money laundering is still always associated with criminal acts, whether it comes from cases of corruption, narcotics-psychotropic, human trafficking, fraud, banking, insurance and so on. Article 69 of the Money Laundering Law states that the crime of money laundering can be declared as an independent offense regardless of the original crime, so that assets can be tracked and confiscated the proceeds of money laundering. However, in Article 75 of the Anti-Money Laundering Law, it is stated that if an investigator finds sufficient preliminary evidence of the occurrence of a crime of money laundering and a predicate crime, the investigator combines the investigation of the predicate crime with the investigation of the crime of money laundering and shall notify the PPATK.[6]

\section{FINDINGS AND DISCUSSION}

\section{Legal and Economic Correlation in Money Laundering}

Based on the provisions of Article 69 of Law Number 8 of 2010 concerning the Prevention and Eradication of the Crime of Money Laundering, the formulation of which is as follows: "In order to be able to carry out investigations, prosecutions, and examinations in court proceedings against the crime of money laundering, it is not obligatory to first prove the crime of origin." [7]

Based on Article 2 paragraph (1) of Law Number 8 of 2010 concerning the Prevention and Eradication of the Crime of Money Laundering, the crime referred to as a predicate crime is the laundering of the proceeds of a crime whose crime is not included in Article 2 paragraph (1) Law Number 8 of 2010 concerning the Prevention and Eradication of the Crime of Money Laundering, so the predicate crime is not a money laundering crime.[8]

Judging from the formulation of the formulation of Article 69 of Law Number 8 of 2010 concerning the Prevention and Eradication of the Crime of Money Laundering, this means that the crime of money laundering is a criminal act that can be carried out in a criminal procedure which includes the stages of investigation, prosecution and examination in court proceedings without having to first prove the crime of origin, for example against the crime of money laundering whose original crime is in the form of a criminal act of corruption, then to carry out an investigation, prosecution and examination process in a trial for a case of the crime of money laundering. Thus, it is not necessary to wait for the proof of the predicate crime which is form of corruption.[9]

\section{Law Enforcement of the Crime of Money Laundering as an Economic Crime}

What must be paid attention is to what extent the basic doctrine of a country in global life is not considered as globalization obstacles, to what extent global aspirations in various social lives can be utilized without sacrificing national identity. As an example, it can be stated whether economic crimes in the future can still be qualified as crimes against constitutions or as crimes against the global economic system.[10]

Efforts to enforce or actually function legal norms as a guide for actors in traffic or legal relations in social and state life are called law enforcement. Or in general, law enforcement can be interpreted as the act of applying certain legal instruments to impose legal sanctions to ensure compliance with the stipulated provisions. Law enforcement is an effort to realize the ideas and legal concepts that are expected by the people to become a reality. Law enforcement is a process that involves many things.[11]

According to Satjipto Rahardjo, law enforcement is a process to make the wishes of the law (the thoughts of the legislature formulated in legal regulations) come true. These factors have a close interrelated relationship, which are the essence and benchmarks of the effectiveness of law enforcement. These factors are:1) Law;2) Law enforcers, namely the parties that form and apply the law;3) Facilities or facilities that support law enforcement efforts;4) Society, where the law is applied;5) Culture, as a result of human initiative in social life.[12]

Lawrience M. Friedman argues that the effectiveness and success of law enforcement depends on three elements of the legal system, namely the structure of law), substance of law and legal culture. The legal structure concerns law enforcement officers, legal substance includes statutory instruments and legal culture is a living law adopted in a society. Another aspect of the legal system is its substance. What is meant by substance is the rules, norms, and patterns of real human behavior in the system. Therefore, the substance of the law concerns the applicable laws and regulations that have binding power and become guidelines for law enforcement officers.[13]

Legal culture concerns legal culture which is human attitude (including the legal culture of law enforcement officers) towards the law and the legal system. No matter how well the arrangement of the legal structure to carry out the stipulated legal rules and no matter how good the quality of the legal substance that is made without the support of legal culture by the people involved in the system and society, law enforcement will not run effectively.[14] Structure is a pattern that shows how the law is carried out according to its formal provisions. This 
structure shows how the courts, lawmakers and law enforcement officers as well as the legal process run and run. In Indonesia, for example, if we talk about the structure of the Indonesian legal system, it includes the structure of law enforcement institutions such as the police, prosecutors and courts.[15]

Based on the formulation of the provisions contained in Article 69 of Law Number 8 of 2010 concerning the Prevention and Eradication of the Crime of Money Laundering, it is intended to show that the crime of money laundering as referred to in Article 3, Article 4, and Article 5 is an independent crime. According to Satjipto Rahardjo, "Law can function to control society and can also be a means to make changes in society". Criminal law policy as one of the efforts in tackling crime in rational criminal law enforcement, consists of three stages, namely:1) Formulation stage; 2) Application stage;3) Execution stage.[16]

The law enforcement process at the formulation stage has made changes to active legislation and is expected to be effective in overcoming money laundering crimes. Currently, regarding the eradication of money laundering in Indonesia, it is regulated in Law Number 8 of 2010 concerning the Prevention and Eradication of the Crime of Money Laundering, replacing the previous law that regulates money laundering, namely, Law Number 15 of 2002 as amended by Law No. Number 25 of 2003.[17]

Financial Transaction Reports and Analysis Center, hereinafter abbreviated as PPATK, is an independent institution established in the context of preventing and eradicating the crime of Money Laundering. Thus PPATK is a legal structure (legal institution) in Indonesia, especially in the field of finance as law enforcement, in the enforcement of money laundering crimes. The Center for Financial Transaction Reports and Analysis (PPATK) classifies money laundering actors into two classifications, namely active money laundering actors and passive money laundering actors.[18]

Active money laundering actors are the perpetrators who meet the criteria in Article 3 and Article 4 of Law Number 8 of 2010 concerning the Prevention and Eradication of the Crime of Money Laundering, the perpetrator of money laundering is at the same time the perpetrator of the predicate crime and is the party who knows or should suspect that the assets originate from the proceeds of the crime. Meanwhile, passive money laundering actors, the perpetrators in accordance with the provisions of Article 5 as above are parties who enjoy the benefits of the proceeds of crime and participate in hiding or disguising the origin of assets.[19]

The emergence of the economic crime of money laundering is to give legitimacy to illegally obtained funds. Basically, the money laundering process in financial institutions or banks can be grouped into three stages of activity, namely: placement, layering and integration.[20]
The application and execution stages concerns with the application of criminal law to perpetrators of money laundering crimes by law enforcement officers as an effort to overcome and eradicate crimes in the economic field, and lex specialis derogate legi generalis principle is applied for the examination of the case. Investigations, prosecutions, and examinations in courts as well as the implementation of decisions that have permanent legal force against criminal acts.[21] It is based on Law Number 8 of 1981 concerning Criminal Procedure Code (KUHAP), unless otherwise stipulated in the Money Laundering Law. Law enforcement is also carried out not contrary to the needs, awareness and public order.[22]

\section{CONCLUSION}

The government's policy in an effort to protect the country's economy against money laundering is enacted by the Anti-Money Laundering Law. The most prominent weakness of the law enforcement strategy against the crime of money laundering so far is that a harmonious and synergistic coordination system has not been established between parties related to the money laundering regime, such as: reporting parties, supervisors and regulators such as PPATK, institutions with special authority and law enforcement officers, especially between Police Investigators and special investigators such as the KPK, the Prosecutor's Office and Judges, so as to hinder the acceleration of eradicating the crime of money laundering. It is necessary to build the concept of harmonious coordination and synergistic cooperation with all law enforcement officers by optimizing the application of the provisions of Article 88 to Article 93 of Law Number 8 of 2010. In the case of money laundering, the police and public prosecutors also have difficulties in proving the occurrence of the crime of money laundering because the modes vary and usually there is no sufficient legal evidence, so that suspects and defendants must be able to prove the origin of their assets not from the proceeds of criminal acts as regulated in Article 77 of the Money Laundering Law. The strategic steps of law enforcement officers in eradicating the crime of money laundering are to improve the management of investigations; asset tracing method to the suspect's property with the concept of follow the money. Therefore, confiscation can be carried out to restore state losses.

\section{REFERENCES}

[1] Yuliandri, G. A. K. R. Handayani, T. Prasetyo, K. Seregig, and H. Tegnan, "Retributive justice theory and the application of the principle of sentencing proportionality in Indonesia," J. Leg. Ethical Regul. Issues, vol. 21, no. 4, pp. 1-8, 2018.

[2] A. Tyson, "Blasphemy and judicial legitimacy in Indonesia," Polit. Relig., vol. 14, no. 1, pp. 182-205, 2021.

[3] A. D. Nuryanto, "Problem Penyidikan Tindak Pidana 
Pencucian Uang yang Berasal dari Predicate Crime Perbankan," Bestuur, vol. 7, no. 1, p. 54, 2019.

[4] A. K. Jaelani and R. D. Luthviati, "The Crime Of Damage After the Constitutional Court's Decision Number 76 / PUU-XV / 2017," J. Hum. Rights, Cult. Leg. Syst., vol. 1, no. 1, pp. 31-41, 2021.

[5] A. A. Singh and V. S. McKleroy, "'Just getting out of bed is a revolutionary act': The resilience of transgender people of color who have survived traumatic life events," Traumatology (Tallahass. Fla)., vol. 17, no. 2, pp. 34-44, 2011.

[6] D. R. Jatmiko, Hartiwiningsih, and G. A. K. R. Handayani, "A political communication regulation model in local leaders election and legislative election for realizing a just political education," Int. J. Adv. Sci. Technol., vol. 28, no. 20, pp. 349-352, 2019.

[7] J. Saravanamuttu and M. Mohamad, "The Monetisation of Consent and its Limits: Explaining Political Dominance and Decline in Malaysia," $J$. Contemp. Asia, vol. 50, no. 1, pp. 56-73, 2020.

[8] Y. K. Teh, "Money politics in Malaysia," J. Contemp. Asia, vol. 32, no. 3, pp. 338-345, 2002.

[9] V. Vithiatharan and E. T. Gomez, "Politics, economic crises and corporate governance reforms: Regulatory capture in Malaysia," J. Contemp. Asia, vol. 44, no. 4, pp. 599-615, 2014.

[10] I. Iswantoro, "Strategy and Management of Dispute Resolution, Land Conflicts at the Land Office of Sleman Regency," J. Hum. Rights, Cult. Leg. Syst., vol. 1, no. 1, pp. 1-17, 2021.

[11] E. Bogdanova, "Obtaining redress for abuse of office in Russia: The Soviet legacy and the long road to administrative justice," Communist Post-Communist Stud., vol. 51, no. 3, pp. 273-284, 2018.

[12] L. C. Lintang, Adriano Martufi, and J.W. Ouwerker, "The Alternative Concepts of Blasphemy Law in Indonesia: Legal Comparison with Ireland and Canada," Bestuur, vol. 8, no. 2, pp. 121-128, 2020.

[13] S. R. Novikasari, D. Q. Ly, and K. Gershaneck, "Taxing Micro, Small and Medium Enterprises in Yogyakarta: Regulation and Compliance," Bestuur, vol. 9, no. 1, 2021.

[14] D. E. Wibowo, "Ewuh Pakewuh Cultural Reconstruction to Equal Consumer Protection," $J$. Best., vol. 8, no. 1, pp. 1-8, 2020.

[15] Prasetio et al., "Problems of democratic and dignified election in indonesian simultaneously electoral era," Int. J. Criminol. Sociol., vol. 9, pp. 1701-1708, 2020.

[16] Z. O. Jainah and I. G. A. K. R. Handayani, "Religious terrorism," Int. J. Adv. Sci. Technol., vol. 28, no. 20, pp. 500-506, 2019.

[17] I. G. Ayu Ketut Rachmi Handayani, Pujiyono, and S. D. Sari, "Forensic and toxicological tests for protecting the patients of esthetic beauty clinic as the constitutional right in Indonesia," Indian J. Forensic Med. Toxicol., vol. 14, no. 2, pp. 2543-2547, 2020.

[18] I. D. M. Suartha, "Criminal Policy Formulation on Regulation of Death Penalties for Criminal Actors,"
J. Moral. Leg. Cult., vol. 1, no. 1, p. 12, 2020.

[19] Saidah Fasihah Binti Che Yussoff and R. Nordin, "Freedom of Expression in Malaysia: Compatibility with the International Human Rights Standard Saidah," Bestuur, vol. 9, no. 1, pp. 44-59, 2021.

[20] U. K. Mishra and A. Negi, "Transgender and the Right to Employment in India: Analysing the Trajectories of Discrimination," Bestuur, vol. 9, no. 1, pp. 34-43, 2021.

[21] W. B. Putri et al., "Medicolegal Perspective on Physician-Induced Demand Issue," Bestuur, vol. 9, no. 1, pp. 106-124, 2021.

[22] S. D. Baranyanan, "Simplification of Law Regulations in Copyright Criminal Act Settlement," J. Hum. Rights, Cult. Leg. Syst., vol. 1, no. 2, pp. 80-91, 2021. 